\title{
William Notman's Portrait Photographs of Girls Reading from the I86os to I880s: A Pictorial Analysis Based on Contemporary Writings
}

\section{Loren Lerner*}

From the I86os into the I88os, the Notman Photographic Studio in Montreal produced numerous portraits of girls reading. ${ }^{\mathrm{I}}$ Unlike boys, who were pictured with a hoop or baseball bat, fishing, riding a bicycle, playing with a toy boat, toppling a garden chair or holding a fur rug as if it were a hunter's trophy, the girls were usually posed as if caught in the act of reading (Figure I). At various stages in her development, Notman's girl subject stood or sat alone or grouped with siblings and parents, a book in her hands or by her side. Always portrayed at her best, her hair was carefully styled and her body was attired in sensible everyday clothing or a lovely dress. ${ }^{2}$

* Loren Lerner is a professor of art history at Concordia University, Montreal. In 2005, she was the curator of "Picturing Her: Images of Girlhood" at the McCord Museum. Her writings on the images of children appear in Canadian Children's Literature/Littérature canadienne pour la jeunesse, Journal of Canadian Art History, and Healing the World's Children: Interdisciplinary Perspectives on Child Health in the Twentieth Century, edited by Cynthia Comacchio, Janet Golden, and George Weisz (Montreal: McGill-Queen's University Press, 2008). Lerner is editor of Depicting Canada's Children (Waterloo, ON: Wilfrid Laurier University Press, 2009).

I The photographs, located in the Notman Photographic Archives at the McCord Museum of Canadian History, are available on the Museum's website, http:// www.mccord-museum.qc.ca (accessed 2I April 2009). See also the text on the website by Stanley G. Triggs, "The Photographic Studio of William Notman," based on Le Studio de William Notman: Objectif Canada / William Notman's Studio: The Canadian Picture (Montreal: McCord Museum of Canadian History, 1992).

2 Interview with Cynthia Cooper, Curator of Costume and Textiles, McCord Museum, 8 April 2008. 


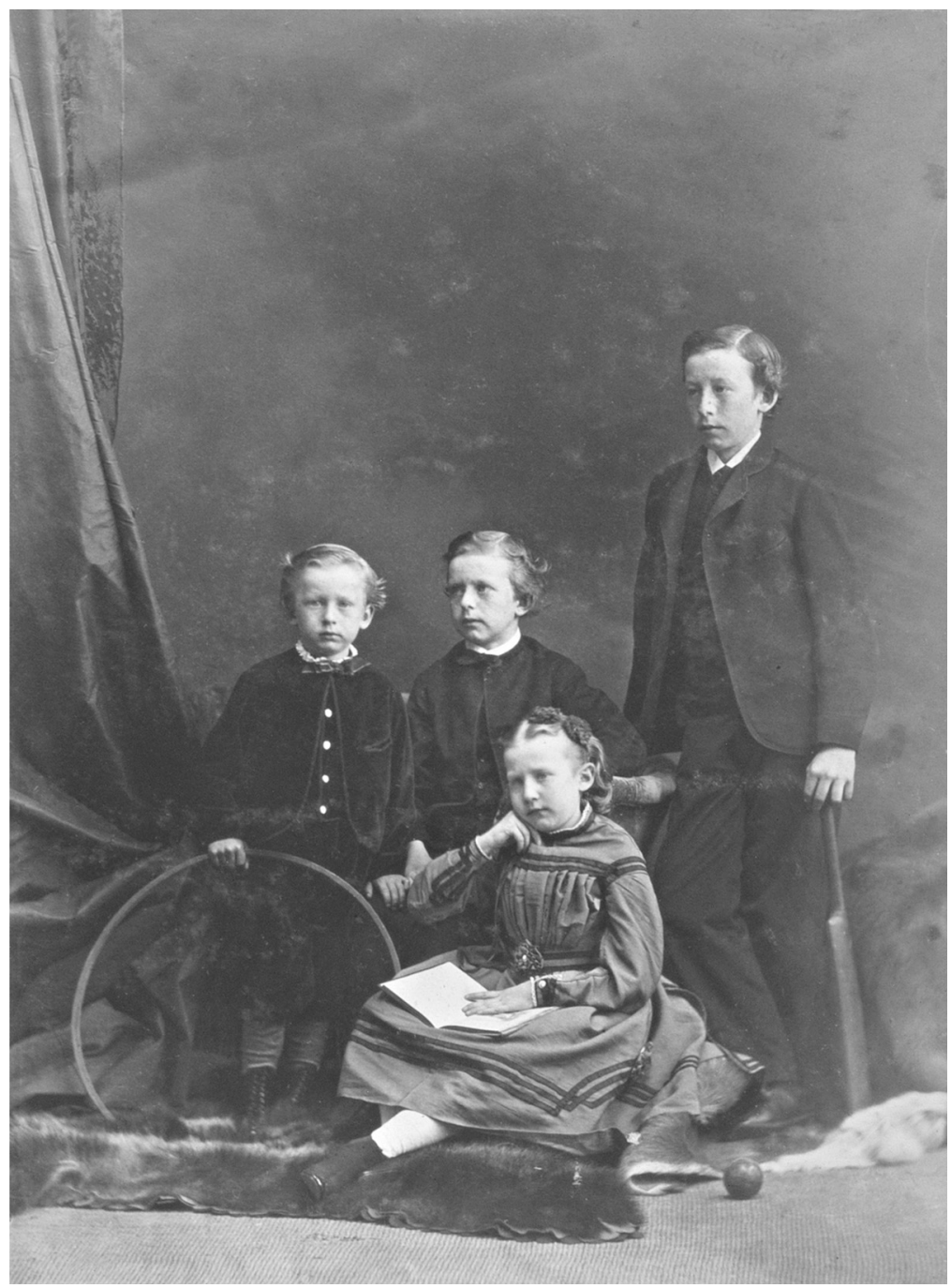

Figure I - Mrs. Smith's children, Montreal, QC. William Notman. I869. Silver salts on paper mounted on paper - Albumen process.

$$
\text { I3.7 } \times \text { IO cm. I-37646.I }
$$

This study proposes that William Notman's (I857-I89I) photographs of girls reading - each one a variation on a carefully constructed pictorial theme agreed upon by the photographer and his clients - 
present a generic image of "the girl reader." In posing his subjects in this way, Notman intended to communicate to family, friends, and to the girl herself the ideals of an effective upbringing, which were invariably associated with reading. The common destination for these portraits was the photographic album, a familiar household object now that photographs were more affordable. ${ }^{4}$

Bound in fine leather and in some cases gilded and embossed with decorations, the family album was often prominently displayed and acted as a social focus and conversation piece for members of the household and relatives, friends, acquaintances, and suitors who came to visit. Everyone was welcome to view the photographs, which captured the development of the daughters of the house. The presence of the girl reader in the album confirmed the middle-class status of the family, for whom reading the right books in the private sphere of the home was considered essential. These portraits of girls convey the mythos surrounding the raising of girls, in particular the idea that their maturation as thinking, articulate people could be achieved through reading.

To better understand the meaning of the portraits in question, this study turns to Canadian writings as well as to publications from England, France, and the United States that were circulating

3 Pictures of the female reader with various encoded meanings proliferated in Europe from the eighteenth century well into the nineteenth century in conjunction with longstanding debates on the proper education of women and their role in society. By the second half of the nineteenth century girls reading books had become associated with leisure time and the ideal of the middle-class home. Notman's portrayal of the female subject was a devotion shared by artists such as Thomas Sully (Portrait of a Girl Reading, I842), James McNeill Whistler (Reading by Lamplight, 1858), and Edouard Manet (Reading, ca. 1865 ) to name only a few of the many artists who expanded the depiction of reading females to include girls with books. His pictures of the reading girl also partake of some of the compositional devices similar to those used by wellknown photographers Lewis Carroll, Roger Fenton and André Adolphe-Eugène Disdéri, whose images Notman studied in his search for established conventions. Yet, unlike these artists and photographers who only occasionally depicted girls reading, Notman's girl with a book was a typical pose for his portraits of the Montreal girl.

4 Martha Langford, Telling Pictures and Showing Stories: Photographic Albums in the Collection of the McCord Museum of Canadian History (Montreal: McCord Museum of Canadian History), available at http://www.mccord-museum.qc.ca/ en/ (accessed 2I April 2009). 
in Canada during this period. ${ }^{5}$ The assumption of this interpretive paradigm is that the imagery of the girl reader contains information that relates to the social and cultural inferences made in these texts. By extrapolating from the texts, this study will demonstrate how an investigation of published material can reveal more explicitly the messages embedded in Notman's photographs of the reading girl. At the same time, it will be shown that the photographs support, document, and comment on the texts. ${ }^{6}$

It is important to emphasize that this study is a pictorial essay. ${ }^{7}$ Its focus on the image in relation to text is a preliminary investigation intended to encourage research on the history of girl readership in Canada. While pivotal studies have considered the women reader ${ }^{8}$ and books and magazines written for Canadian women during this

5 These publications are available through Early Canadiana Online (ECO), http://www.canadiana.org/eco (accessed 2I April 2009), a growing digital library that provides access to over two million pages of Canada's printed heritage to the early twentieth century. Also included on ECO is non-Canadian reading material disseminated in Canada and widely read by Canadians.

6 For a discussion of the interrelations of image and text during the Victorian era, see Julia Thomas, Pictorial Victorians: The Inscription of Values in Word and Image (Athens: Ohio University Press, 2004).

7 My interest in the girl reader began with paintings of girls by Canadian women artists. See Lerner, "From Victorian Girl Reader to Modern Woman Artist: Reading and Seeing in the Paintings of the Canadian Girl by William Brymner, Emily Coonan, and Prudence Heward," Canadian Children's Literaturel Littérature canadienne pour la jeunesse 33 (2) (Autumn 2007): 19-50. Writings on the image of the female reader include: Linda J. Docherty, "Women as Readers: Visual Interpretations," Proceedings of the American Antiquarian Society I07, pt. 2 (1997): 335-88; Stefan Bollmann, Reading Women, foreword by Karen Joy Fowler (London: Merrell Publishers, 2006); Catherine J. Golden, Images of the Woman Reader in Victorian British and American Fiction (Gainesville: University Press of Florida, 2003); Antonia Losano, "Reading Women/Reading Pictures: Textual and Visual Reading in Charlotte Bronte's Fiction and Nineteenth-Century Painting," Reading Women: Literary Figures and Cultural Icons from the Victorian Age to the Present, Janet Badia and Jennifer Phegley, eds. (Toronto: University of Toronto Press, 2005), 27-52; and Garrett Stewart, The Look of Reading: Book, Painting, Text (Chicago: University of Chicago Press, 2007).

8 See Badia and Phegley, eds., Reading Women, Catherine J. Golden, Images of the Woman Reader in Victorian British and American Fiction, Kate Flint, The Woman Reader 1837-I9I4 (London: Oxford Clarendon Press, 1993); and Mary Kelley, Private Woman, Public Stage: Literary Domesticity in NineteenthCentury America (Chapel Hill: University of North Carolina Press, 2002). 
era 9 little attention has been devoted to the reading practice of girls ${ }^{10}$ and the meaning of this practice within larger literary and cultural contexts. The objective of this study is to show that Notman's work with his young female subjects is but one part of a much wider Victorian cultural production that includes a large variety of writings on reading and the proper growth and development of girls.

What girls should read and how this would affect their growth and development was the subject of numerous advice manuals, novels, magazine articles, and books written especially for and about girls. Some writers were very concerned about the dangers of young girls reading the wrong books. In 1884, in Serious Hours of a Young Lady, the author Charles Sainte-Foi warns girls that "The country is flooded with productions that sap the foundations of morality... flimsy productions of depraved minds, which, besides all the other injuries they cause, rob them (the young ladies) of a most precious time."II Francis E. Clark uses even stronger language in Looking Out on Life: A Book for Girls on Practical Subjects Based on Many Letters from Wise Mothers written in 1892. "Better never learn your letters than to read about unholy love and seduction and divorce and the horrible sin... Better have the leprous scales on your face, where they will only ruin physical beauty and comeliness, than have them on the heart, where

9 Research on female reading in Victorian Canada has been devoted to writings by and for women, notably, Carole Gerson, A Purer Taste: The Writing and Reading of Fiction in English in Nineteenth Century Canada (Toronto: University of Toronto Press, 1989). For a comprehensive introduction to Canadian authorship, print culture, the illustration of books and magazines, and reading in the nineteenth century, consult Yvan Lamonde, Patricia Lockhart Fleming, and Fiona A. Black, eds., History of the Book in Canada, Vol. 2, I840-I9I8 (Toronto: University of Toronto Press, 2005).

IO Studies of the reading practices of girls outside of Canada include Nancy Tillman Romalov, "Unearthing the Historical Reader, or Reading Girls' Reading," Primary Sources \& Original Works 4 (I-2) (1996): 87-IOI; and Meredith Rogers Cherland, Private Practices: Girls Reading Fiction and Constructing Identity (London: Taylor \& Francis, 1994). For an overview of Anglo-American girl culture during this era, see Sally Mitchell, The New Girl: Girls' Culture in England I880-I9I5 (New York: Columbia University Press, 1995) and Frances B. Cogan, American Girl: The Ideal of Real Womanhood in Mid-Nineteenth-Century America (Athens, Georgia: University of Georgia Press, 1989).

II Charles Sainte-Foi, Serious Hours of a Young Lady, trans. by Philaletes (Montreal: Printed for the author, I884), 284. Charles de Sainte-Foi, Saint-Foix and Saint-Foy were the pseudonyms used by Eloi Jourdain (I807-I86I), a Catholic theologian who lived in France. See Harry W. Paul, "Quest of Kerygma: Catholic Intellectual Life in Nineteenth-Century France," American Historical Review, 75 (2) (December 1969): 387-423. 
they will ruin the purity of the soul." ${ }^{\text {"12 }}$ Taking a completely different approach, one that was gaining ground, in 1896 writer and journalist, Madge Merton, along with the editors of Canadian Magazine, offered a very positive assessment of reading. The "true use of reading," Merton professed, was to "show life as it is - the littleness of its vanity, the unequalled grandeur of its unselfish strength" and "to build character."13 "Girls ought to read all kinds of books, including those that teach something or inspire the reader to learn something... books that honour old age and venerate childhood, that unlock the mysteries of nature, and point to the Divine through them all. ${ }^{\text {'I4 }}$ She continued: "What is right for a woman is right for a man and a girl should read the same books her brother should read.'15

In Canada during those years, writers consistently advanced the benefits of reading and often recommended books by Canadian authors. In Woman, Her Character, Culture and Calling (I890), B.F. Austin calls attention to the fact that in the field of literature especially, Canadians make a "creditable showing, and of those who have contributed to this literature, a considerable number have been women ... Among this sisterhood of writers ... there is much encouragement in the fact of a constant increase in the numbers of those who are living the higher life and keeping company with truth, goodness and beauty." ${ }^{16}$ With the rise of female readers, women

I2 Francis E. Clark, Looking Out on Life: A Book on Practical Subjects Based on Many Letters from Wise Mothers (Boston: D. Lothrop, I892), 79. Francis Edward Clark (I85I-I927) was an American Congregational minister and founder of the Christian Endeavor Society, one of the first evangelical youth ministries in the United States. Clark was born of New England ancestry in Aylmer, Quebec. See John Fea, American National Biography, vol. 4 (New York: Oxford University Press, 1999), 926-27.

I3 Madge Merton, "Our Children and their Reading: Part II-A Girl's Reading," Canadian Magazine 9 (I) (January 1896): 285-87. Madge Merton was a pseudonym for Elmina Elliott Atkinson (I867-1931), a journalist who wrote a column for the Toronto Globe and the Toronto Star and was society editor of Saturday Night. She was the wife of Joseph Atkinson, owner of the Toronto Star. See Michael Pieri, "Joseph E. Atkinson A Chronology," Atkinson Charitable Foundation, available at http://www.atkinsonfoundation.ca (accessed 2I April 2009); and The Canadian Who's Who, I9Io (Toronto: Musson Book, 1910), 8.

I4 Merton, "Our Children and their Reading," 285.

I5 Merton, "Our Children and their Reading," 286.

I6 B.F. Austin, Woman, Her Character, Culture and Calling: A Full Discussion of Woman's Work in the Home, the School, the Church and the Social Circle, with an Account of her Successful Labors in Moral and Social Reform (Brantford, ON: Book and Bible House, I890), I04. Benjamin Fish Austin (I850-I933), a Canadian 
authors in Canada and elsewhere were writing novels for mothers and daughters that extolled the difference that reading made to a girl's intellectual growth and general maturity. In stories such as The Tree of Knowledge (1889) by Mrs. Baillie Reynolds, Brooke's Daughter (I89I) by Adeline Sergeant and Marguerite Verne, or, Scenes from Canadian Life (I886) by Rebecca Agatha Armour girls are portrayed either as avid readers or as non-readers whose lives are about to be changed by deriving knowledge from reading. For example, Miss Brabourne in The Tree of Knowledge is a girl of nineteen who, because she "had read astonishingly little" was considered "utterly unformed," with a "dull expression" that "looked as if the girl had no thoughts." ${ }^{17}$ In Brooke's Daughter, the daughter "was not only pure and innocent, but she was ignorant, she did not know how the poor lived: she had only the vaguest and haziest possible notions concerning misery and want and disease" until she was awakened by "the strong and burning words which she was reading." 18 Armour's protagonist Marguerite Verne, already a keen reader, tells her mother: "Don't mind me, mamma. Please bear in mind I am good company for myself. I remember once reading a passage in some book which said that all the pleasure we derived had its source in ourselves, and not in external objects. I often think of it, and believe it to be true." ${ }^{9}$

educator and Methodist minister, was the first Principal of Alma College for women from I88I to 1897. Survival Research Institute of Canada, 2007, available at http://www.islandnet.com/ -sric/Austin_Benjamin_Fish.pdf (accessed 2I April 2009).

I7 Mrs. Baillie Reynolds, The Tree of Knowledge: A Novel (Montreal: J. Lovell, I889), II. Mrs. Baillie Reynolds (I875-1939), a British author who also published under her maiden name, Gertrude Minnie, or Gertrude M. Robins, wrote numerous stories and novels, including ghost stories and Crime Club mysteries. She was elected president of the Society of Woman Journalists in 1912. See "Outside the Gates: Women,” The British Journal of Nursing, 23 November 1912, 423, available at http://rcnarchive.rcn.org.uk (accessed 2I April 2009); Acorn Books, http:// www.acornbooksinmi.com (accessed 2I April 2009).

I8 Adeline Sergeant, Brooke's Daughter: A Novel (Montreal: J. Lovell, I89i), Io8. Adeline Sergeant (I85I-1904) whose full Christian names were Emily Frances Adeline was a British author of over ninety novels and tales. See Dictionary of National Biography, Second Supplement, ed. Sidney Lee, 29I.

I9 Rebecca Agatha Armour, Marguerite Verne, or Scenes from Canadian Life (Saint John, NB: s.n., I886), I6. Rebecca Agatha Armour (née Thompson) (I845-I89I) was a Canadian author and teacher in New Brunswick who published at least two other novels during her lifetime. See Gwendolyn Davies, Dictionary of Canadian Biography Online, I89I-1900, vol. XII (Toronto: University of Toronto/ Université Laval, 2000), available at http://www.biographi.ca (accessed 2I April 2009). Subsequent references to this online site were accessed the same date. 
The plots of these novels by women typically revolve around the home, family life, the upbringing of girls, female friendships, the trials and tribulations of courtship, and the tensions surrounding women's emotional needs and intellectual pursuits. This viewpoint was also clearly echoed in books about home culture, such as All Around the House, or, How to Make Homes Happy by Mrs. H.W. Beecher $(\mathrm{I} 88 \mathrm{I})^{20}$ and Woman, Her Character, Culture and Calling (I890) already cited. In the I870s, the Montreal-based magazine Canadian Illustrated News frequently visited the subject of book learning for girls and participated in training them for household responsibilities through articles like "What to Teach Our Daughters,"2I "The Best Education" 22 and "What to Do With the Girls." ${ }^{23}$ In "Hearth and Home - Female Education," for example, the author emphasizes that literature gave a girl "real and proper weight in society" when used with "proper discretion," and would not make her unfit for the "everyday business of life" and "homely objects." 4

In keeping with "Hearth and Home - Female Education," Miss Cramp (Figure 2) stands posed in a lovely dress, the book in her hand and another on the table indicative of the learning from books valuable for a girl's successful entry into society. The portrait taken in Notman's studio includes a variety of furnishings and props arranged to simulate the "everyday business of life" and "homely objects" of a Montreal home. ${ }^{25}$ The intimate interior space contributes to the sense

20 Mrs. H.W. Beecher, All Around the House, or, How to Make Homes Happy (Toronto: J. Robertson, I88I). Mrs. Henry Ward Beecher (Eunice White Bullard Beecher) (1813-1897) was the wife of the noted liberal Congregational minister and abolitionist from Boston. She is also author of Motherly Talks with Young Housekeepers (New York: J.B. Ford, I873), composed of brief articles that originally appeared in The Christian Union, a magazine established by her husband. See "The Life of Mrs. Beecher," New York Times, 9 March I897, I2; and University of Delaware Library, Special Collections Department, "Defining Her Life: Domestic Economy," available at http://www.lib.udel.edu/ud/spec/ exhibits/women/domestic.htm (accessed 2I April 2009).

2I Author Unknown, "What to Teach our Daughters," Canadian Illustrated News (I2 December I874): 375 .

22 Author Unknown, "The Best Education," Canadian Illustrated News (I2 December I874): 375 .

23 Author Unknown, "What to Do With the Girls," Canadian Illustrated News (3 June I876): 363 .

24 Author Unknown, "Hearth and Home - Female Education," Canadian Illustrated News (19 May 1877): 307.

25 Interview with Nora Hague, Photographic Archivist, Notman Photographic Archives, McCord Museum of Canadian History, 9 April 2008. 
of peace that infuses the girl's private activity. We are encouraged to cherish the aesthetics of this middle-class home, and the emotional connection between the girl and the books that have captured her attention.

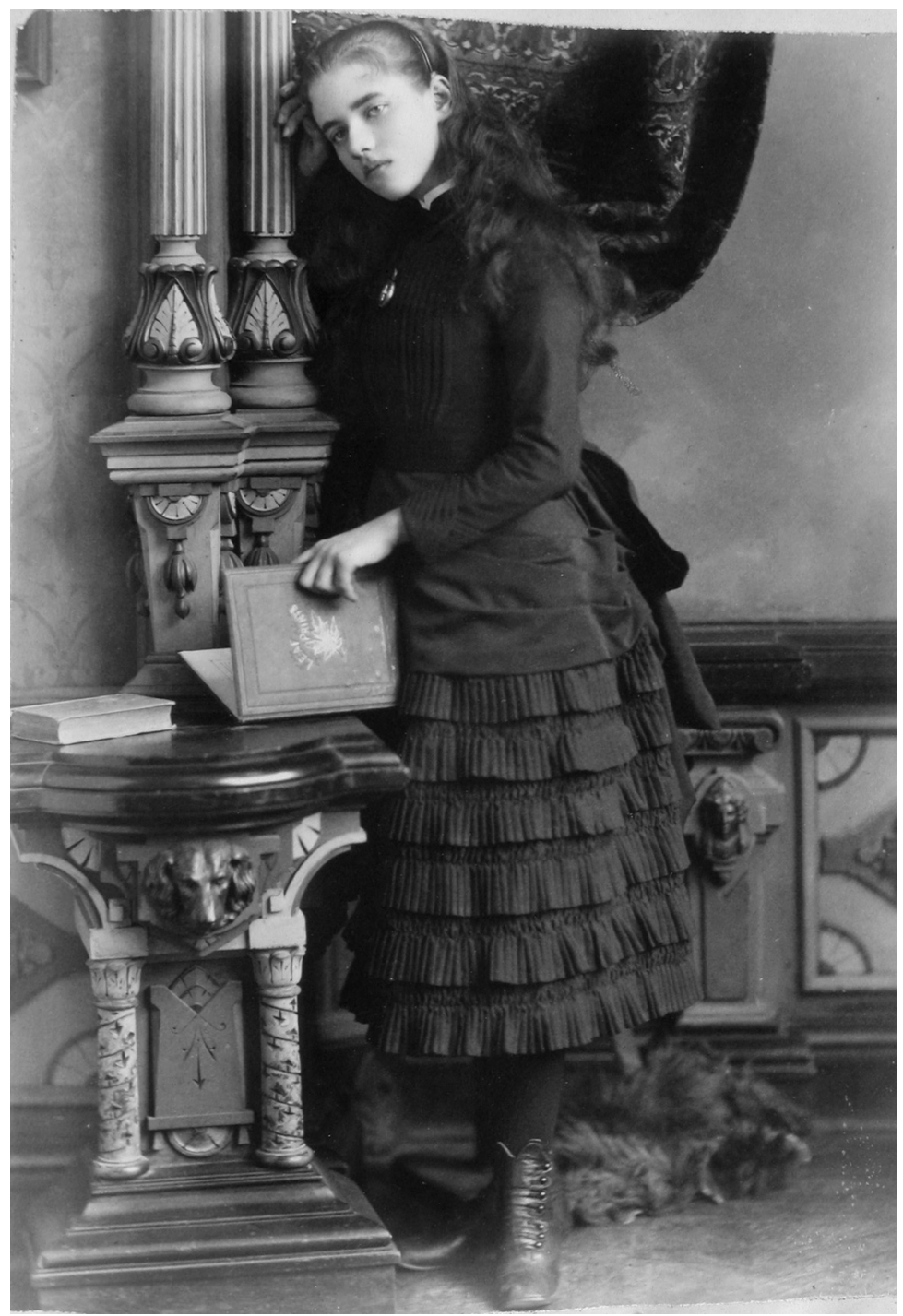

Figure 2. Missie Cramp, Montreal, QC. Wm. Notman \& Son. November 22, I882. Silver salts on paper mounted on paper - Albumen process.

$$
\text { I5 } \times \text { IO cm. II-67479.I }
$$


In this photograph the face of Miss Cramp is visible in threequarter view, her eyes turned slightly to the left, her head resting on a column. Out of respect for the modesty and lack of vanity expected of girls, Notman usually instructed his subjects to avert their gaze from the viewer, as if their likeness was being captured without them purposefully posing for the camera. This, one assumes, was the formula Notman perfected to best represent the facial features of his young female subjects. As such, the portraits were based on a limited amount of characterization, a repetition of motifs, and a typology of fashionable beauty, with variations achieved by using slightly different viewpoints for the face and figure. Notwithstanding this formulaic composition, these portraits also convincingly convey the girl reader as a thinking person with a soul.

Miss Cramp's left hand is holding the book open while her right hand gently touches the column where she rests her head. With her pensive look, she is a perfect illustration of ideas about the thinking girl, what we want most to see in a girl, according to Maud Cooke, author of Social Etiquette, or, Manners and Customs of Polite Society: Containing Rules of Etiquette for All Occasions (1896). ${ }^{26}$ A clear light illuminates her facial features, revealing bright eyes, full rosebud lips, and a healthy complexion. The shape of her body, accentuated by the sash that cinches her waist, hints at the blossoming of "the sweet curves of the lithe form that come but once in a lifetime." ${ }^{27}$ Suitably clothed in an outfit that is simply cut and fashionable, her attire imparts the "speech of her body." 28 But Cooke explains that we are to focus not on the dress but on the girl who is its soul. Whatever the communicative potential of Miss Cramp's costume and other elements of the portrait, it is in the subject's face, particularly her eyes, that we will find suggestions of character.

26 Maud C. Cooke, Social Etiquette, or Manners and Customs of Polite Society Containing Rules of Etiquette for All Occasions (London, ON: McDermid and Logan, I896). Maud C. Cooke was an American writer on social customs and cookery who was well known in Canada. Cooke's books included Breakfast, Dinner and Supper (Brantford, ON: 1897), Three Meals a Day (Chicago: Educational Co. 1902) and Our Deportment (Philadelphia: National Publishing in Philadelphia, 1902).

27 Cooke, Social Etiquette, 395.

28 Cooke, Social Etiquette, 389 . 


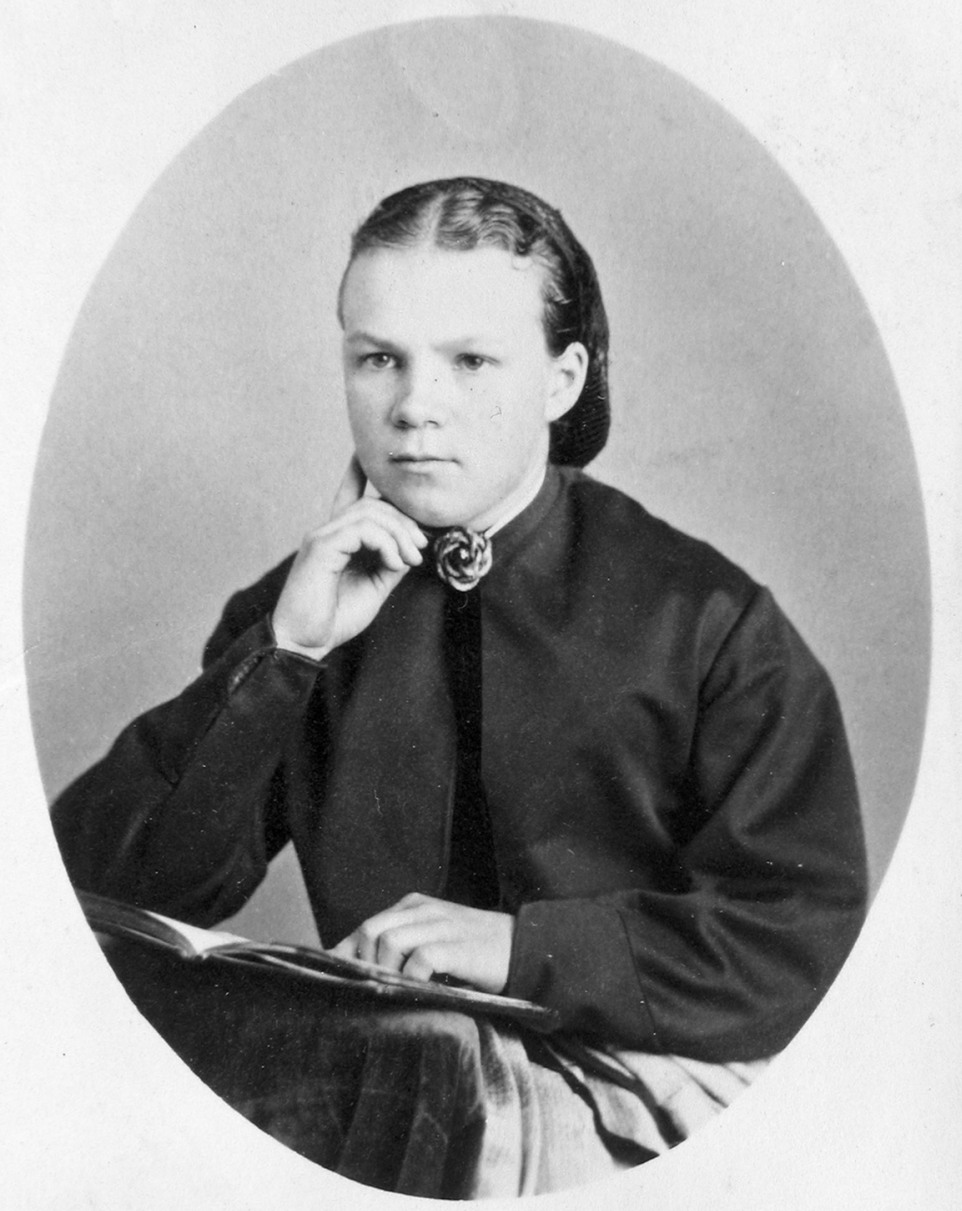

Figure 3. Miss Jacobi, Montreal, QC. William Notman. 1867. Silver salts on paper mounted on paper - Albumen process. 8 x $5 \mathrm{~cm}$. I-280I8.I

In this photograph, Miss Cramp's eyes are raised as if she is meditating on what she has just read. In another of many examples of this pose Miss Jacobi (Figure 3), a seemingly more serious girl, sits with a book on her lap in a close-up portrait set in an oval frame. With this look of contemplation, the girls are reflecting the methods 
and merits described by Canadian writers who took on the task of defining the right way for girls to read. In her article on children's reading in Canadian Magazine (I896), Madge Merton underscores the conviction that "Assimilation of thought and inspiration for thinking are the true objects of serious reading." 29 One writer for Northern Messenger (1897) insisted that for a child to strengthen her memory, all she had to do was absorb what she had read by pausing to think about it: "After reading a book or an article, or an item of information from any reliable source, before turning your attention to other things, give two or three minutes quiet thought to the subject that has just been presented to your mind to see how much you can remember concerning it, and, if there were any new ideas, instructive facts, or hints of special interest that impressed you as you read... the very effort to think the matter out will engrave the facts deeply upon your memory - so deeply that they will not be effaced by the rushing in of a new and different set of ideas." ${ }^{30}$ Seen from the viewpoint of these writings, there is no doubt that Miss Cramp and Miss Jacobi are thinking about their reading, imagining and remembering what they are in the process of absorbing, having understood the educational benefits that come from reading properly.

A picture of Mr. and Miss Ellis (Figure 4) offers some information about the home reading environment and how girls read in relation to the members of their family. In this photograph Miss Ellis, a girl about ten years old, is standing beside her father, who is sitting on a chair in front of a table holding a large book. In this family portrait, which calls to mind the home library, the father appears to be sharing a reading with his daughter because authorities on the subject have declared that being read to forms a girl's taste for reading. For this reason, mothers and fathers have been told, they should read to their daughters before they can spell or even hold a book. "The time to form a girl's taste for reading is before she begins to read. Her mother, her father, her home environment, her baby outlook on life will have set her feet in one or another direction before she can spell the words or hold the book." ${ }^{\mathrm{I}}$

A girl in her father's library being read to or reading her father's books was a recurring image in novels about the fine breeding of an

29 Merton, "Our Children and their Reading," 286.

30 Author Unknown, "To Strengthen the Memory," Northern Messenger, 32 (47) (I9 November 1897): 7.

31 Merton, "Our Children and their Reading," 285. 


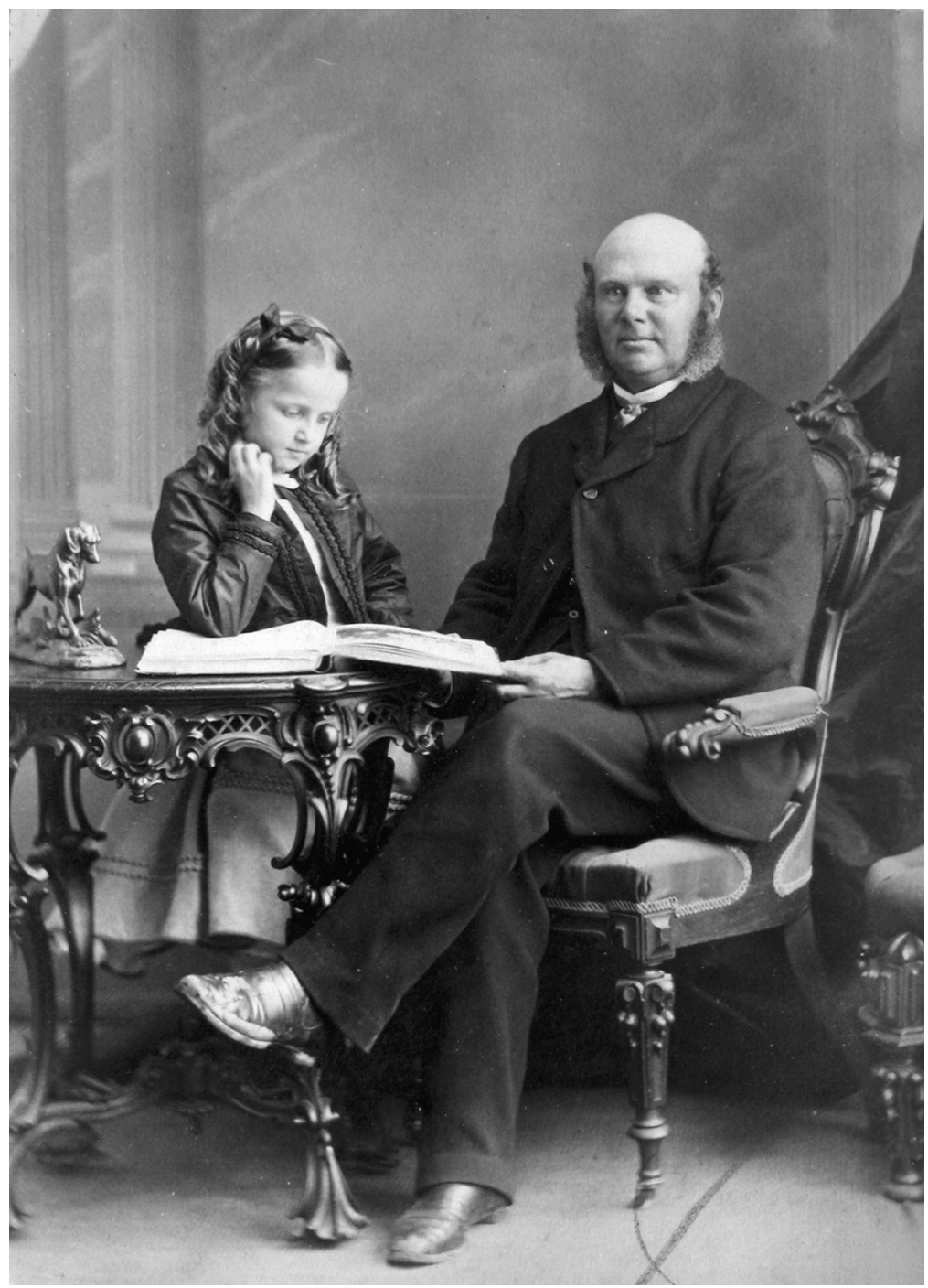

Figure 4. Mr. and Missie Ellis, Montreal, QC. William Notman. I868. Silver salts on paper mounted on paper - Albumen process. 8.5 x $5.6 \mathrm{~cm}$. I-3I9IO.I

educated girl. Susanna Moodie writes in Matrimonial Speculations (I854): "I was a romantic girl, brought up in the deepest seclusion, and having free access to my father's library, had read all the novels 
and romances of the last century." ${ }^{22}$ In James De Mille's The Cryptogram (I87I), Zillah's taste for reading led her to be familiar with the best authors, and in this way she learned from her father a sense of honour and natural instinct. In her father's library she "would sit for hours curled up on a window-sill, reading tales, Arthur and the Knights of the Round Table, or of Charlemagne and his Paladins. Fairy lore, and whatever else our medieval ancestors have loved, thus became more familiar to her, and all her soul became imbued with these bright and radiant fancies." ${ }^{33}$

Books were considered essential to the proper and successful raising of a family. "A dreary place is a bookless home, my young friends; see that in founding a home for yourselves you do not neglect the household library," warns a writer in Canadian Independent magazine in $1879 .{ }^{34}$ The author continues: "We rejoice in pretty furniture and artistic pictures; but we want to see a new book sandwiched between every two purchases, and newspapers and magazines drifting around so thickly that the very order of the sitting room is imperilled ... So parents remember this, glance over your libraries to see if there be not some vacancy to fill up with the volume which will add to the cheer of the windy wintry nights."

In Notman's composite photographs ${ }^{35}$ of the families of Andrew Allan (I87I), Philip S. Ross (I876) (Figure 5), J. Scott (I877) and W. Angus (I88I), books are everywhere, on chairs, tables, the floor, and in bookshelves, and nearly everyone is involved either in reading

32 Susanna Moodie, Matrimonial Speculations (London: R. Bentley, I854), 45. Susanna Moodie, née Strickland (I803-1885), was a British-born Canadian author who wrote numerous poems, children's tales, short stories, articles and novels. Moodie is best known for Roughing It in the Bush (New York: Putnam, I852), a personal narrative of her settler experiences in Canada. See Carl P. A. Ballstadt, Dictionary of Canadian Biography Online, I88I-I890, vol. XI (Toronto: University of Toronto/Université Laval, 200o), http:/www.biographi.ca.

33 James DeMille, The Cryptogram: A Novel (New York: Harper, I87I), 25. James DeMille (I833-1880), a Canadian author born in New Brunswick, was professor of classics at Acadia College, who subsequently taught history and rhetoric at Dalhousie College. His novels which appeared serially in American magazines were later published as books in New York and Boston by Harper, Appleton, and other publishers. See Minerva Tracy, Dictionary of Canadian Biography Online I87I-I880, vol. X (Toronto: University of Toronto/Université Laval, 2000), http://www.biographi.ca.

34 Author Unknown, "Bookless Homes," The Canadian Independent 26 (I3) (November 1879): 3 .

35 Stanley G. Triggs, The Composite Photographs of William Notman (Montreal: McCord Museum of Canadian History, 1994). 


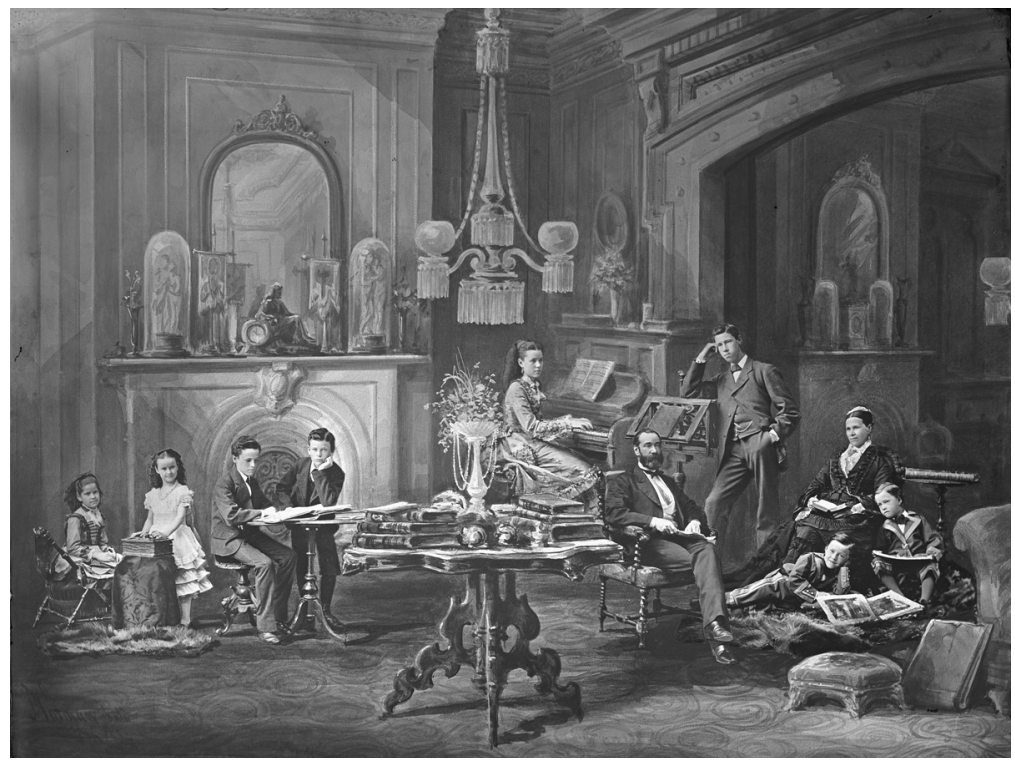

Figure 5. Philip S. Ross and family, Montreal, QC, composite. Notman \& Sandham. I876. Silver salts on glass - Wet collodion process. $20 \times 25 \mathrm{~cm}$. II-4I408

or being read to. The painted backdrops onto which the photographs of the family members were pasted accurately depict the splendid residences of these wealthy Montreal families. These were homes rich with fine furnishings, musical instruments, paintings, and sculpture. A close inspection reveals the written word in all forms - as books, newspapers, and letters - while nearby there are photographic albums and folios of illustrations. This is most apparent in the portrait of Philip Ross's family, in which a large round table holding piles of books and a vase of flowers is conspicuously placed front and centre. The table's size, perhaps purposefully out of perspective, nearly dwarves the family members who are sitting or standing behind it. Painted in brown tones against a black-and-white gouache background and mounted in a bird's-eye maple-and-walnut frame, this photograph was prominently displayed for many years in the Ross home. ${ }^{36}$

In this era before the advent of public libraries, girls in Montreal found their reading material in the home library. As Reginald Gourlay lamented in "Women's Sphere - Public Libraries" fellow Canadians needed to "awoke from our slumber" and build public libraries

36 Interview with Nora Hague. 
as "part of our education system." ${ }^{37}$ Even as reading clubs were organized such as the Canadian Branch of the Girls Friendly Society in 1882 and The National Home Reading Union of Canada in I895, and small lending libraries, schools, and churches were developing their first book collections, the home library was the mainstay of a child's education. ${ }^{38}$ As such, it is not unexpected that Notman should depict girls in studio settings with furnishings arranged to simulate the parlours, sitting rooms, and libraries of a Montreal home. Occasionally however the girl may also enjoy the outdoors in the company of her schoolmates and friends, as we can see in the composite photograph of the Bute House School (Figure 6), one of the many English schools for girls in Montreal that offered a liberal education. The girls partake in the same activities they do at home and with family, picnicking, with a book nearby, in spring.

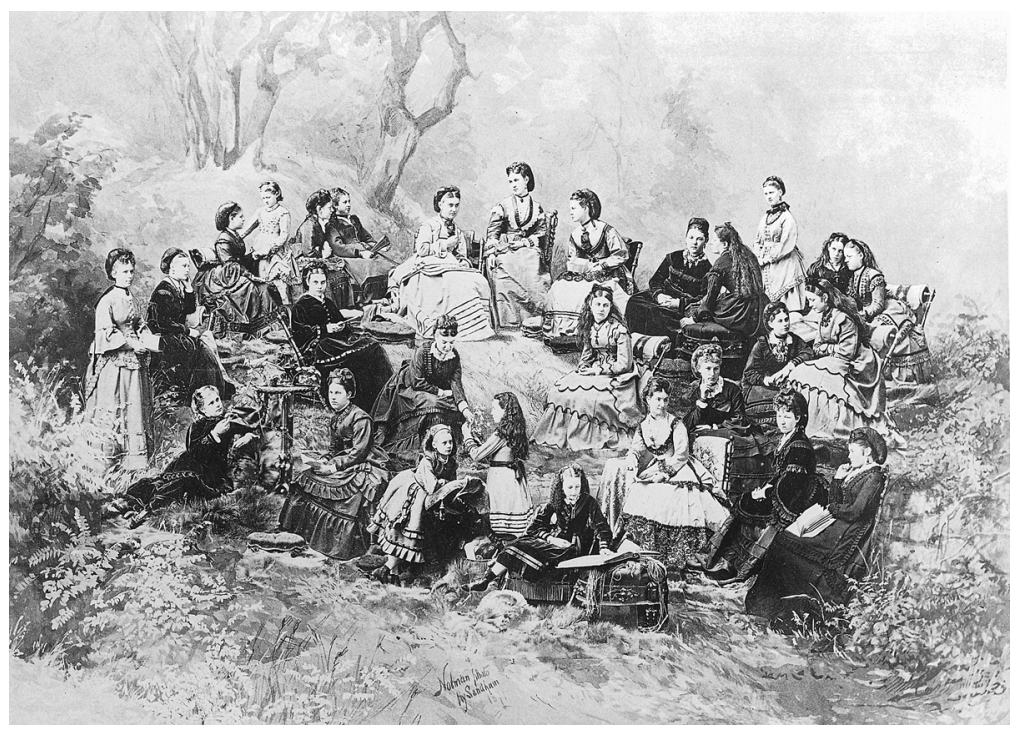

Figure 6. Bute House school group, Montreal, QC, composite. William Notman. I87I. Silver salts on paper mounted on card - Albumen process.

$20.3 \times 25.4 \mathrm{~cm}$. N-0ooo.73.10

37 Reginald Gourlay, "Women's Sphere - Public Libraries," Canadian Magazine I7 (July I90I): 285-86. Reginald Gourlay, known as a sportsman and naturalist, wrote poems, short stories, and editorial comments for Canadian Magazine in the late nineteenth and early twentieth century.

38 National Council of Women of Canada, Women of Canada and Their Life and Work (1900), 269. 
Judging from the repetition found in Notman's photographs, the books his clients "read" were from a collection he kept at his studio. Like the furnishings and other decorative details of his portraits, the books appear to reflect the assortment of reading material found in the average middle-class and upper middle-class Montreal family home. Especially prevalent in Notman's photographs of girls is the illustrated book or magazine. The Stephens sisters (Figure 7), comfortably attired in their school dresses, are reading a publication that is brimming with landscape drawings. Also interested in illustration is Miss H. Bagg (Figure 8), considerably younger, dressed fussily in a silk taffeta confection. She stands before a large-size journal resting on a chair, having stopped to look at a lithograph of a woman.

When creating scenes that showed Montreal girls with illustrated books and magazines, Notman was confirming the value of the illustrated publication in educating girls, and his own interest in art and illustration. Notman's first book was Photographic Selections, ${ }^{39}$ published in 1863 "to foster an increasingly growing taste for works of art in Canada." The book featured photographs of paintings, mostly by old masters. Two years later he published a second volume that consisted of his own photographs from nature and photographic reproductions of the works of contemporary Canadian painters. ${ }^{40}$ In I864, Notman published North American Scenery, ${ }^{41}$ which presented landscape paintings by Charles Jones Way. Between I865 and I868 he collaborated with John Fennings Taylor on a three-volume set of biographies with portraits titled Portraits of British Americans. ${ }^{42}$ Then, from I869 to I883 Notman frequently contributed photographs of people, places, and events to Canadian Illustrated News, ${ }^{43}$ a Montreal magazine published by George Desbarats, noted for its innovative half-tone photo-engravings.

39 William Notman, Photographic Selections, with descriptive letter press by Thomas D. King (Montreal: W. Notman, I863).

40 William Notman, Photographic Selections, with descriptive letter press by Thomas D. King, second series (Montreal: W. Notman, 1865).

4I Charles Jones Way and William Notman, North American Scenery being selections from C.J. Way's studies, I863-64 (Montreal: W. Notman, I864).

42 Fennings Taylor and William Notman, Portraits of British Americans by W. Notman with Biographical Sketches by Fennings Taylor (Montreal: W. Notman, I865-68).

43 Canadian Illustrated News (Montreal: George Desbarats, I869-I883). For illustrations see Canadian Illustrated News: Images in the News, http://www. collectionscanada.gc.ca/databases/cin (accessed 6 May 2009). 


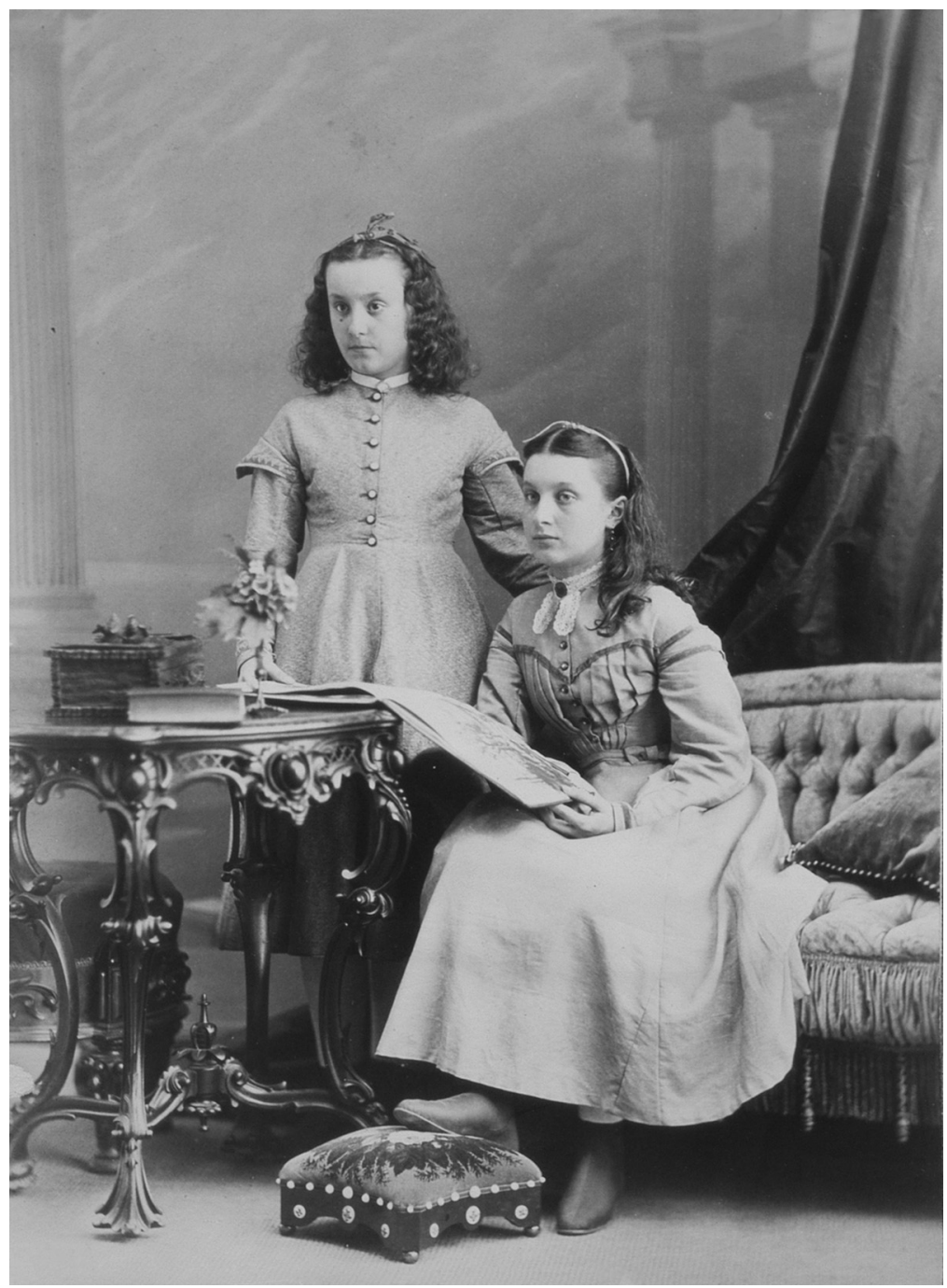

Figure 7. Misses Stephens, Montreal, QC. William Notman. I868. Silver salts on paper mounted on paper - Albumen process. $17.8 \times \mathrm{I} 2.7 \mathrm{~cm}$. I-32I28.I 


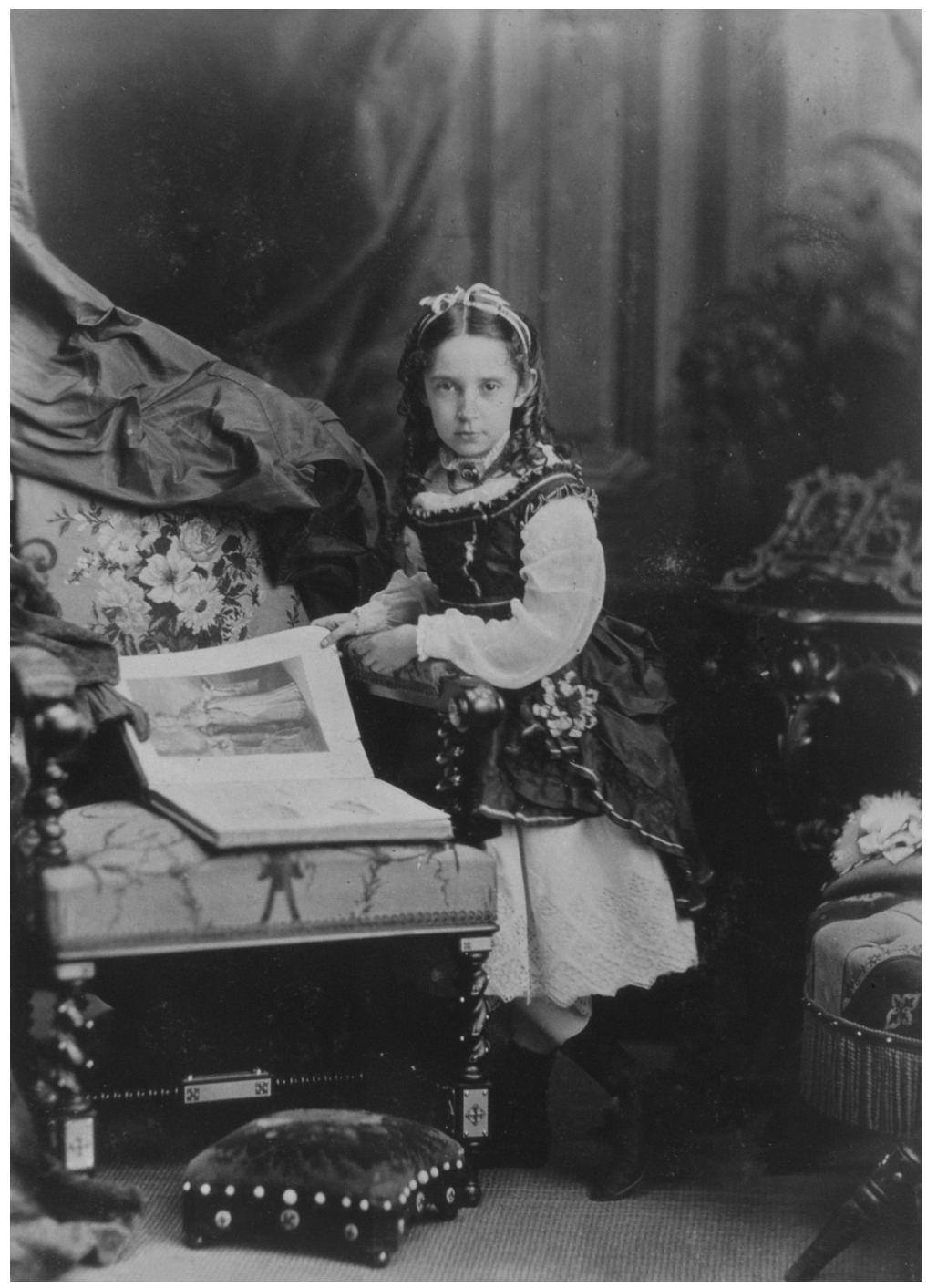

Figure 8. Miss H. Bagg, Montreal, QC. William Notman. I870. Silver salts on paper mounted on paper - Albumen process. $17.8 \times 12.7 \mathrm{~cm}$. I-47090.I 
These views on art and reading were also embraced by Canadian educators and commentators. In an address delivered at Oxford and published in Lectures and Essays (I88I), Goldwin Smith writes, "Certainly this age is not indifferent to beauty. The art movement is in every house; everywhere you see some proof of a desire to possess not mere ornaments but something really rare and beautiful. The influence transmutes children's books and toys." ${ }^{44}$ In an article in The Canada School Journal (I883), the writer maintains that "It is not enough that our young folks see all these things from the street, in the shop or art gallery, but the best of literature, art and music should be simplified and given to them daily as a matter of course." 45 Northern Messenger's way of capitalizing on the public's new interest was to frequently announce that subscribers to this magazine who obtained "a permanent home library or club circulating library of a hundred volumes, more or less," could be sure that "the books are nicely printed and handsomely bound in cloth and many of them finely illustrated." 46

While books of a religious nature were a staple of the publishing industry, it is noticeable that unlike earlier representations of the female reader, the Bible or Christian commentaries never overtly appear in his photographs of girls. While a mother will occasionally appear with her daughters holding a prayer book in her hands, this is not the case with girls reading on their own. Indeed, if any of the girls had been holding a Bible, one would expect to see a look of pious concentration on her face. This absence is significant because

44 Goldwin Smith, Lectures and Essays (Toronto: Hunter, Rose, 188I), 80. Goldwin Smith (I823 - I9IO), a British-Canadian historian, writer, and journalist was Regius Professor of Modern History at Oxford University and professor of English and constitutional history at Cornell University before settling in Toronto in I87i. Smith played a prominent role in the development of some Canadian periodicals, including the Canadian Monthly and National Review, The Nation and The Week, and wrote and published the Bystander, a journal devoted to political and social commentary. See Ramsay Cook, Dictionary of Canadian Biography Online, IgoI-I9Io, vol. XIII (Toronto: University of Toronto/ Université Laval, 2000), http://www.biographi.ca.

45 A.F. Blaisdell, "Culture for Children," The Canada School Journal 8 (73) (July 1883): 154. Albert Franklin Blaisdell (1847-1927) was an American physician and author who wrote numerous textbooks for children on American history, literature, hygiene, and physiology. See Mary L. Perham, "Reading Material for Pupils of the Fourth and Fifth Grades," The Elementary School Journal 22 (4) (December 192I): 298-306.

46 "Books and Money for Messenger Readers, and Pictures Too - How They May Be Obtained," Northern Messenger 24 (24) (29 November I889): 8. 
at the time it was emphasized in every part of society that the Bible was the source of all learning. Writers agreed that "the first reading for the young should always be taken from the Bible, that marvellous book, the grandeur whose imagery and the purity of whose diction is unrivalled in all the world." 47 This theme was constantly repeated in the children's stories of religious magazines like Canadian Independent, The Presbyterian and Northern Messenger. "Every morning little Joan read a chapter in the Bible to her mother. One can never learn about God too early!" 48 is the kind of passage that was typical of these publications. Girls were instructed to focus on biblical literature first and to find exemplars in the Bible, women like Miriam and Deborah who rejoiced in deliverance and victory, and like Hannah who voiced confidence in God. ${ }^{49}$ Presumably, for Notman and his clients, the sanctity of religious teaching and practice was a given and was only enhanced by the appropriate selection of ethical literature. As a schoolteacher writes in Canadian Illustrated News (1883), religious and moral education is not the constant repetition of pious phrases or the hourly training of a set of religious lessons. Rather, religion "should control every art" through "the constant though often unexpressed and scarcely conscious reference of the conduct of the highest motives that the scholar may become self-reliant and may be fitted to guide himself..." ${ }^{\circ}$ In this way, the Bible had been extended to include other kinds of reading that were equally suitable for shaping the good character of the girl.

From childhood into her courtship years the Montreal girl continues to be portrayed with a book. Notman's collection includes

47 Agnes Schultz, Lady Campbell Farquharson, How to Provide Good Reading for Children, read at the National Council of Women of Canada, at Toronto, I895 (Toronto: Bryant Press, I895), 5. Agnes Campbell Farquharson Schultz (I840-1929), born in British Guiana, came to Manitoba with her father James Farquharson in 1864, and married John Schultz in 1867 . She served as hostess at Government House from 1888 to I895. See J.M. Bumsted, Dictionary of Manitoba Biography (Winnipeg: University of Manitoba Press, 1999), Manitoba Historical Society, available at http://www.mhs.mb.ca (accessed 2I April 2009).

48 Author Unknown, "Love and Be Loved," The Canadian Independent II (II September I879): 7 .

49 Rev. Professor A.M. Warner, "Chapter VII, Woman in Literature," in Woman, Her Character, Culture and Calling, 9I.

50 Author Unknown, "Annual Convention of the Ontario Provincial Teachers Association," Canadian Illustrated News (27 October 1883): 258. This emphasis on personal morality is the subject of: Bernd Baldus and Meenaz Kassam, "'Make Me Truthful, Good and Mild': Values in Nineteenth-Century Ontario Schoolbooks," Canadian Journal of Sociology 2I (3) (Summer 1996): 327-58. 
numerous portraits of women during her courting years, each woman attired in a fine dress suitable for visiting or receiving guests at home, each posed gracefully and decorously next to a book. This picture of the mature daughter such as Miss Allan (Figure 9) served as a visual announcement of her readiness for marriage. The intended audience could be the suitor himself or a relative or friend acquainted with a marriage prospect.

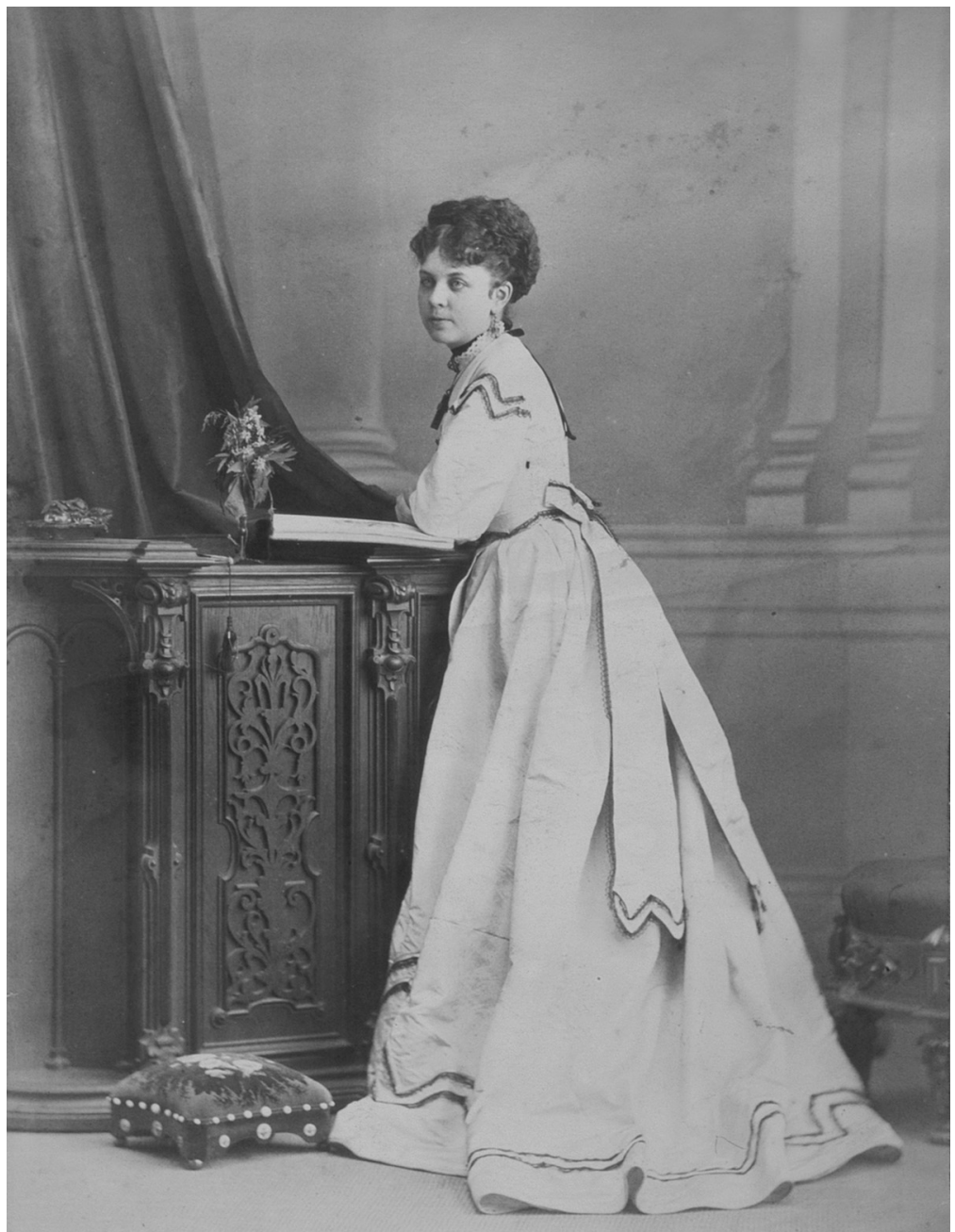

Figure 9. Miss Allan, Montreal, QC. William Notman. I868. Silver salts on paper mounted on paper - Albumen process. $17.8 \times$ I2.7 cm. I-3200O.I 
Late nineteenth-century guidebooks on courtship and marriage help to decipher the meaning of Notman's photograph of the mature girl with a book. It is expected of this woman that, as described by Annie Swan in Courtship and Marriage and the Gentle Art of HomeMaking (1893), her "own innate delicacy and niceness of perception will guide her now to act, and if the attentions be acceptable to her she will give just the right need of encouragement, so that the course of true love may run smoothly towards consummation." 5 I According to the author of The Ladies Book of Useful Information Compiled from Many Sources (1896), "During your courtship let me entreat you to be very careful and circumspect," and, "God has made you a woman; and believe me, as there is no fairer, so there is no nobler creature than woman. She is formed to be her husband's helpmate and the mother of his children, and the all-important work of training these for heaven depends mainly upon her." 52

Like this woman, the girls most frequently depicted in Notman's photographs were upper middle-class city women, enticing marriage prospects for the young men able to win their affections. Miss Allan has the appeal of Adeline Sergeant's Nan Pynsent in Name and Fame (I890). "The girl wore an embroidered muslin, with a yellow sash tied loosely round her slender waist ... The sweet, delicate face, with its refined features and great dark eyes, was one which might well cause a man to barter all the world for love; and in Sydney's case, it happened that to gain its owner meant to gain the world as well. It spoke well for Sydney's genuine affection that he had ceased of late to think of the worldly fortune that Nan might bring him, and

5I Annie Swan, Courtship and Marriage and the Gentle Art of Home-Making (Toronto: W. Briggs, I893), I2. Annie Shepherd Swan (I859-I943), a Scottish author, initially wrote stories for children and articles for The Christian Leader. Her literary career progressed in the early 1890 os when she moved to London where she contributed to women's magazines and wrote the letter-columns "Over the Teacups" and "Love, Courtship and Marriage" for the monthly periodical, Woman at Home (1893-1920). Swan also wrote under the names of Mrs. Burnett-Smith, her married name, and the pseudonym, David Lyall. See The National Archives of Scotland, "Annie Shepherd Swan," available at http://195.I53.34.9/onlinecatalogue/welcome.aspx (accessed 21 April 2009); and Edinburgh University Library, Special Collections Division, Letters of Annie Shepherd Swan (1859-1943), available at http://www.archiveshub.ac.uk (accessed 2I April 2009).

52 The Ladies Book of Useful Information Compiled from Many Sources (London, ON?: s.n., I896), 76. 
remembered only that he wanted Nan Pynsent for herself." 53 The Ladies Book of Useful Information Compiled from Many Sources warns: "When a young woman has property or expects it, or is possessed of superior personal attractions, she should be especially prudent in her conduct towards the numerous admirers which such qualifications attract." 54

In fact, wealthy girls like these were a small minority in Canada where most people struggled to make a living on a farm or in a factory. As such, rich girls were sometimes criticized for their elitist upbringing and superficial social life. An article titled "Our Fashionable Girls" in Canadian Agriculturist (I85I) quotes Miss Swisshelm of the Pittsburgh Saturday Visitor on the spoiled behaviour of the rich city girl: "There are hundreds of girls in every large city who parade in the streets, in feathers, flowers, silks and laces, whose hands are as soft and white as uselessness can make them... The evenings are devoted to dressing, displaying their charms and accomplishments to the best advantage..." 55

The writer of "Our Fashionable Girls" responds that country girls are very different. They do not live idly, but keep busy in the autumn "putting up pickles or preserves, apples, butter, sausages and sauces for future uses." Many years later in I896 in a similar endorsement of country life Reginald Gourlay argues in his article on the Canadian girl that a young woman living in the "backwoods" possesses a better, more genuine education than city girls. She has "a frank kindliness of manner, an innocent self respect, and the remarkable equipoise and common sense which is to be found in her as well as in her more cultured sister. Add to this an intense desire for self improvement, and for such culture as she can grasp ... The girls in frontier places read more than all the rest of the family put together, and often amazingly good books. I have seen letters from some outlaying districts like Algoma, in which farmers' daughters quote Eliot, Scott, Tennyson, Macaulay, and even Browning, with a zest and appreciation not always found in those who have more opportunities and more time to cultivate such authors." 56

53 Adeline Sergeant, Name and Fame: A Novel (Montreal: J. Lovell, 1890), 23637.

54 The Ladies Book of Useful Information, 79.

55 Author Unknown, "Our Fashionable Girls," Canadian Agriculturist 3 (4) (April I85I): 93.

56 Gourlay, "The Canadian Girl," Canadian Magazine, 7 (4) (August I896): 507. 
The upbringing of wealthy girls was criticized because the girls were seen as socialites whose lack of work experience and peculiar liberal education failed to prepare them for the realities of life such as a downturn in the family's economic fortunes or the death of a parent. Our Girls (187I) by Dio Lewis, reprinted in Toronto from an American edition, focuses on what girls should wear, fashionable outrages that torture girls' bodies, how girls should walk, idleness among girls, false gentility, and preparing for matrimony. One chapter, however, looks at working opportunities for women. Based on the five hundred employments listed in Virginia Penny's The Employments of Women, published in Boston in 1863, it suggests positions "which are pursued almost exclusively by men," but are suitable for women including bank clerks, brokers, copyists, dentists, lawyers, lecturers, librarians, physicians, preachers, proofreaders, publishers, architects, engravers, photographers, gardeners, merchants, carpenters, and teachers of gymnastics, drawing and painting. ${ }^{57}$ Louisa May Alcott, the well-known author of Little Women, writes in The Canadian Independent (I885) that a girl needs "a profession or trade to fall back upon in time of need, that she may not be dependent or too proud to work for her bread." ${ }^{8}$ An article on "Boy and Girl Marriages" in Canadian Illustrated News (I883) reiterates this viewpoint: "Our girls are not taught to do anything thoroughly. They play a little, they sing a little, more often than not very badly; they paint, perhaps, a little, and speak a little French, German or Italian, but should a reverse of fortune occur they cannot teach one of their accomplishments, they cannot even cut out a gown or mend a shirt. What they like best is to angle for husbands. When the object is caught they don't know what to do with him." 59

57 Dio Lewis, Our Girls (Toronto: Adam, Stevenson, I87I), 84-IIo. Diocletian Lewis (I823-I886), commonly known as Dr. Dio Lewis, was an American temperance leader who practised homeopathy. A pioneer in physical education, he advocated hygiene, exercise and an active life for women. See Photothèque Homéopathique présentée par Homéopathe International, available at http:// homeoint.org/photo/l/lewisd.htm (accessed 2I April 2009).

58 Louisa M. Alcott, "The Education of Girls," The Canadian Independent 4 (I) (January, I885): 28. Louisa May Alcott (I832-1888) was an American novelist, best known for the novel Little Women, published in I868. See Katharine M. Rogers, American National Biography, vol. I (New York: Oxford University Press, 1999), 23I-34.

59 Author Unknown, "Boy and Girl Marriages," Canadian Illustrated News (6 January I883): 3 . 
Towards the end of Woman, Her Character, Culture and Calling, Austin writes about the creation of colleges for women. He states, "When the future historian of this century sits down to describe the intellectual life of this age no feature of his subject will be more marked and interesting than the founding and growth of colleges for women. ${ }^{" 60}$ A photograph taken by Notman in 1870 (Figure Io) shows Miss Sweetsey as a student at Vassar College in Poughkeepsie, New York. This is one of many such portraits taken by Notman in studios he set up at several northeastern American colleges. Here, Miss Sweetsey is posed in a domestic setting modified to resemble a college residence. Wearing a fashionable dress, she reads her course notes or practices a recitation while a book rests on a nearby table. In this photograph, a new type of woman appears whose reading is no longer related to the home but is directly associated with her studies at college. ${ }^{\text {GI }}$

We may never know the many particulars of the lives of the girls in Notman's photographs. Unlike the original viewers of these portraits, we are unable to visit the girls at home and look at their pictures in the family album. Nonetheless, these Montreal girls from the late nineteenth century compel our attention and inspire us to decipher the meanings and circumstances of their lives. In the poem "To a Young Girl with an Album" (I88I), Mrs. Leprohon expresses the desire that gentle Lily, who receives a photograph album as a present, will grow up pure and joyful: "As the pages of this volume, unwritten, stainless, fair,/Life opens out before thee, let it be thine aim and care/To keep the record spotless and ever free from all/ That thou might'st wish hereafter remorseful to recall." ${ }^{162}$ The poet's hopes

60 Austin, Woman, Her Character, Culture and Calling, 423.

61 By the time of Notman's death in I89I, the portrait of the girl with a book was no longer the norm. As the options for school, work, and a profession slowly became available, and photographic images became more spontaneous, the reading girl was replaced by a new kind of young woman, more active, independent, and urbane than the reserved girl who reads at home.

62 Mrs. Rosanna Eleanor Leprohon (Miss R.E. Mullins), The Poetical Works of Mrs. Leprohon (Montreal: J. Lovell, I88I), 218. Rosanna Eleanor Mullins Leprohon (I829-1879), a Canadian author born in Montreal, wrote novels, as well as poems and short stories that appeared in the Literary Garland. Her most well known works are The Manor House of De Villerai: A Tale of Canada under the French Dominion, printed in installments by the Montreal Family Herald (I859-1860), Antoinette de Mirecourt: or, Secret Marrying and Secret Sorrowing (Montreal: Lovell, I864), and Armand Durand: or, A Promise Fulfilled (Montreal: Lovell, I868). The Poetical Works of Mrs. Leprohon, edited by the poet John Reade, was published 


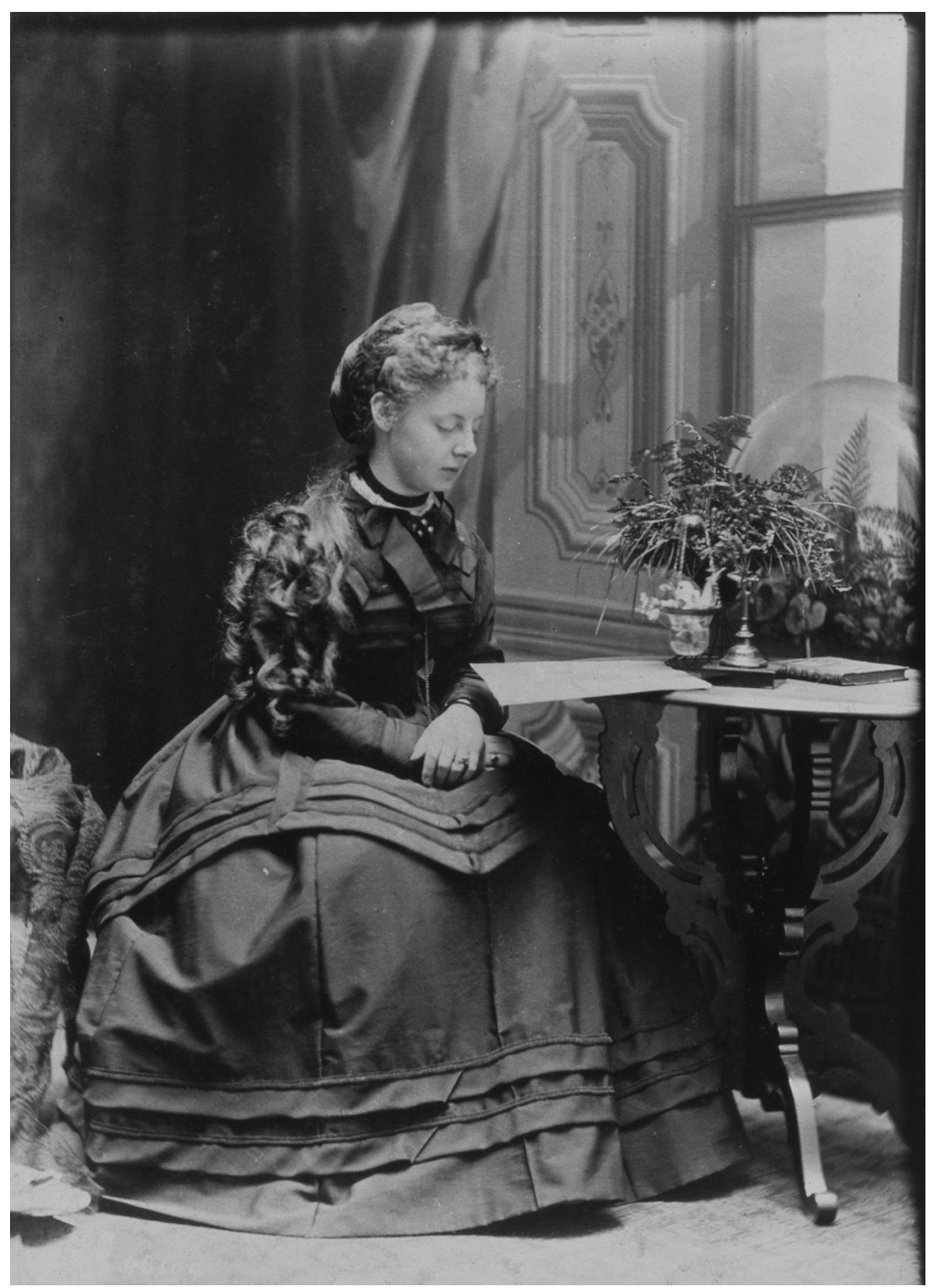

Figure Io. Miss Sweetsey, student, Vassar College, Poughkeepsie, NY. William Notman. I870. Silver salts on paper mounted on paper - Albumen process. I $7.8 \times$ I2.7 cm. I-46594.I 
for Lily mirror society's hope that girls will happily comply with the path that has been laid out for them.

This study of Notman's photographs of the girl reader, which takes into account texts such as the one above that comment on reading, female behaviour, and the proper upbringing of girls, has led to some initial observations. First, the portraits reveal that society expected its daughters, through reading, to become thinking, articulate people. We also see how reading increased a girl's sense of self-worth as, at every stage of her development, she widened her literary and visual imagination and expanded her knowledge through reading. As well, the texts disclose concerns that girls were only being prepared for marriage and raising a family and were deprived of the type of education that would give them the skills they needed to be selfsufficient.

As a preliminary investigation, this essay opens up the arena for further bibliographic research on the reading experiences of the Canadian girl and the importance of print culture to her proper education. ${ }^{6}$ The findings suggest the need to investigate the figure of the girl reader not only for evidence that books and magazines are socially charged objects, but to uncover information about the girl's role as a significant cultural phenomenon. Questions to be explored could include why the subject of girls and reading was so important, why it was believed that girls must read, and what advice was given about what, where, when, and how they should read. Special attention to class, ethnicity, and region could also be considered.

Another avenue of exploration could focus on the diverse ways nineteenth-century Canadian girl readers responded to the textual matter they encountered and how they understood their reading experiences. Their reading environment could enter into this type of discussion. For example, did they read alone or with family members, or as part of an institutional or social group such as a school or club?

two years after her death. See Mary Jane Edwards, Dictionary of Literary Biography (2005-2006), available at http://www.bookrags.com/biography (accessed 2I April 2009); and Carole Gerson, Three Writers of Victorian Canada: Rosanna Leprohon, James De Mille, Agnes Maule Machar (Toronto: ECW, 1983).

63 Some of the quotations on reading cited in this essay could be contributed to The Reading Experience Database I450-I945 (RED), available at http://www. open.ac.uk/Arts/reading (accessed 2I April 2009). This is a project launched in 1996 at UK Open University. Its objective is to gather data from written and printed texts on the reading experiences of British subjects from I450 to 1945 . At present, the database has fewer than one hundred entries from Canadian authors, mainly by Lucy Maud Montgomery. 
A further approach could look at the manipulation of the image of the girl reader both in texts and pictures found in books and magazines. In pursuing these and other avenues that are certain to surface from the discovery of new sources and directions, we can learn more about the development of books and journals for young people in Canada and the impact these texts had on the reading practices and literacy of young females. In this way, we can achieve a more thorough comprehension of the impact reading has had on the development of the Canadian girl.

\section{SOMMAIRE}

Cette étude analyse dix portraits de jeunes liseuses croqués au studio de photographie Notman de Montréal entre les années i860 et 1880. Des extraits tirés d'ouvrages canadiens ainsi que de publications en provenance de l'Angleterre, de la France et des États-Unis alors en circulation à cette époque au Canada illustrent à quel point ces textes faisaient partie intégrante des messages véhiculés par les photographies de liseuses de Notman et, inversement, comment ces photographies aidaient à visualiser ces mêmes ouvrages. En mettant ainsi en lumière l'image en relation avec le texte, on vise à encourager la recherche bibliographique sur l'histoire du lectorat féminin et les expériences de lecture de la jeune fille canadienne. 